\title{
DIGITÁLIS TÁVOLSÁGOK A HÁROMSZÖGRÁCSON
}

\author{
NAGY BENEDEK
}

\begin{abstract}
Digitális síknak tekinthetjük a sík egy szabályos csempézésével kapott diszkrét rácsot, mely pontjainak a digitális képfeldolgozásban, illetve számítógépes grafikában megszokott módon magukat a csempéket tekintjük. A háromszögrács, amely háromszögcsempékből épül föl, a három szabályos síkrács egyike. Minden háromszögcsempét (amit a továbbiakban legtöbbször képpontnak, vagy röviden pontnak hívunk) egyedi egészekből álló koordinátahármassal címzünk. A digitális síkban gyakorlati szempontból fontos szerepet játszanak az ún. digitális távolságok, amelyeket a pontok közti utakkal definiálunk. Az utak felépítésében a pontok közti szomszédság alapvető fontosságú. A háromszögrácson minden pontnak háromféle szomszédja van, beleértve a legközelebbi oldalszomszéd csempepárokat, illetve további kétféle típusú csúcsszomszéd csempepárokat. Ezek alapján háromféle (digitális) alaptávolságot értelmezhetünk a pontok közti legrövidebb út (vagy utak) lépésszámaként, amelyeket általánosíthatunk két közismert módon. A szomszédsági sorozatokkal megszabhatjuk, hogy az út hányadik lépésében milyen típusú szomszédság engedélyezett, míg a súlyozott távolság esetén a különböző típusú szomszédokra való lépésekhez különböző súlyokat rendelhetünk, és a legrövidebb összsúlyú út súlya adja a távolságot. Az ezekkel a digitális távolságokkal kapcsolatos eredményeket foglaljuk össze, valamint mutatunk nem metrikus távolságokat, digitális köröket és egyéb érdekes kapcsolódó kutatási irányokat.
\end{abstract}

\section{Bevezetés}

A háromszögrácsokat az utóbbi időben egyre több helyen alkalmazzák a gyakorlatban, többek között geometriai modellezésben, 3D szkennelésnél, valamint szimulációs, grafikai és képfeldolgozási algoritmusokban. Utóbbira jó példa a vékonyító algoritmus [8]. A háromszögrácson a három alapvető szomszédsági viszony már [5]-ben megtalálható (1. ábra, jobb oldal). A digitális távolságokat a rácspontok közötti utak alapján definiáljuk, hasonlóan ahhoz, ahogy a gráfelméletben használjuk a távolság fogalmát $[9,13,14,40]$. Ennek megfelelően a rács struktúrája, a szomszédsági viszony alapvető fontosságú. A háromféle szomszédság 
alapján három alapvető távolságfüggvényt definiálhatunk (3. fejezet). A szomszédsági sorozatokkal definiált távolság a négyzetrácsokra már a 80-as évektől ismert [2, 3, 42, 43]. Háromszögrácsra is értelmezhetőek, de itt a „tér dimenziójánál” eggyel több szomszédságtípussal, ami több matematikailag is érdekes következménnyel jár [16, 17, 18]. A 4. fejezetben algoritmust adunk tetszőleges két pont közötti legrövidebb út meghatározására, illetve megadjuk a szükséges és elégséges feltételét annak, hogy egy tetszőleges szomszédsági sorozattal definiált távolságfüggvény mikor határoz meg metrikus teret. A háromszögrácson több olyan érdekes jelenség is megfigyelhető, amely a négyzetes rácsokon nem tapasztalható. Ezeket a jelenségeket, mint a nem szimmetrikus távolságfüggvény vagy az egymást „megelőző” sorozatok, külön is megvizsgáljuk. Az utolsó alfejezet a digitális körökről szól.

Másik jól ismert alternatíva a digitális távolságok változatos definiálására (és lehetőséget adva pl. az euklideszi távolság jobb közelítésére a digitális síkon), ha a különböző típusú szomszédok közti lépésnek különböző súlyokat adhatunk. Az így kapott súlyozott távolságok [1], ugyancsak adaptálhatóak a háromszögrácsra [32]. Ezeket a távolságokat és tulajdonságaikat tekintjük át az 5. fejezetben. Képletet adunk a távolság kiszámítására tetszőleges rácspontok és súlyhármasok esetére, ahogy lineáris egészértékü programozás segítségével azt is megmutattuk, mikor, milyen lépések, milyen bázis adja az optimális megoldást, a legrövidebb utat [11].

Amint látni fogjuk, a háromszögrácson a digitális távolságok sok érdekes tulajdonsággal rendelkeznek már a szomszédsági sorozatokkal definiált távolságok esetén is. A súlyozott távolságok esetén pedig ugyancsak sokkal érdekesebb távolságokat kapunk, mint a négyzetrács analóg módon definiált távolságai, amit az általuk definiált digitális körökkel reprezentálunk.

A cikkben elsősorban a szerző és szerzőtársai által az utóbbi húsz év ezirányú kutatásait tekintjük át néhány aktív irányt is megemlítve.

\section{A háromszögrács leírása}

A háromszögrácson háromféle szomszédsági viszonyt szokás definiálni [5]. A koordinátákat az 1. ábrán látható módon vezetjük be [19,41]. Jelölje $H$ a rács pixeleinek halmazát. Ekkor matematikailag a következő definíció alapján definiáljuk a szomszédsági relációkat.

2.1. Definíció. Legyen $p=(p(1), p(2), p(3)), q=(q(1), q(2), q(3)) \in H$ két különböző pont a háromszögrácson és $k \in\{1,2,3\}$. A $p$ és $q$ pontok $k$-szomszédok, ha teljesülnek a következők:

1. $|p(i)-q(i)| \leq 1$ minden $i \in\{1,2,3\}$ esetén,

2. $\sum_{i=1}^{3}|p(i)-q(i)| \leq k$.

Ha a második feltételben egyenlőség áll fenn, akkor azt mondjuk, hogy a $p$ és $q$ pontok szigorúan k-szomszédok. 


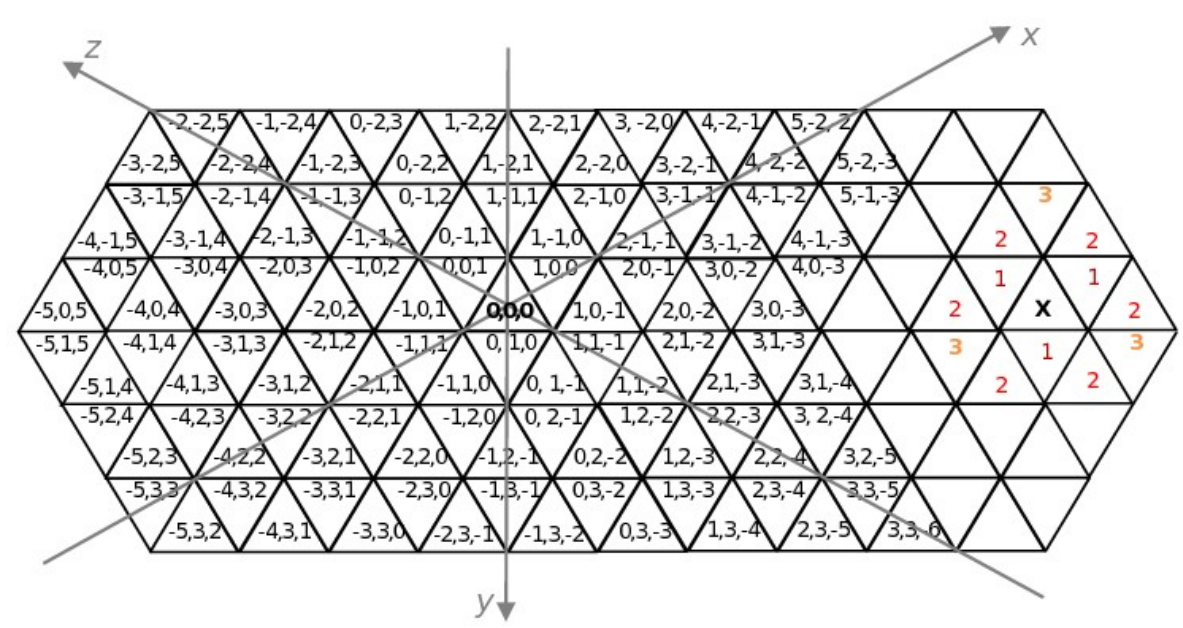

1. ábra. Koordináták és szomszédságtípusok a háromszögrácson, a jobb oldalon a számok az x pont szigorú szomszédait jelölik.

2.2. Definíció. Rögzítsünk le egy koordinátát. Azon pontok, amelyeknek ez a koordinátája megegyezik ezzel a fix értékkel, egy sávot alkotnak.

2.1. Megjegyzés. A $H$ háromszögrács pontjai egy-egyértelműen azonosíthatóak az olyan koordináta-hármasokkal, amelyekre az értékek összege 0 vagy 1.

2.3. Definíció. A 0 koordinátaösszegü pontok paritása páros. Azok a pontok pedig, melyeknek a koordináta-összege 1, páratlanok.

A háromszögek paritás alapján történő csoportosítása megfelel az orientációjuk alapján történő csoportosításnak $(\triangle, \nabla)$, a páros-páratlan megkülönböztetés pedig az eredeti egész számokra vett paritásfüggvény egy kétdimenziós általánosításának, hiszen két élszomszédos, vagyis 1-szomszéd háromszögcsempe paritása mindig különböző. Továbbá ha két pont 1-szomszéd, akkor két különböző sáv is tartalmazza mindkettőjüket. Két szigorúan 2-szomszéd paritása megegyezik, és pontosan egy sávra igaz, hogy mindkettőt tartalmazza. A szigorúan 3-szomszédok paritása különbözik, és nincs olyan sáv, amely mindkettőt tartalmazza.

A következő fogalmak fontos szerepet játszanak a távolságmérésben, hiszen két pont egymáshoz képesti viszonyát jellemzik a rácsban.

Legyen $p, q \in H$ két pont. A $w_{p, q}$ vektort a $p$ és a $q$ pont különbség-vektorának hívjuk, ha $w(i)=q(i)-p(i)$. A pontok paritásától függően $w_{p, q}$ koordinátáinak összege 0 vagy \pm 1 lehet. A $w_{p, q}$-nak mint multihalmaznak az elemeit abszolút értékük nagysága szerint nemnövekvő sorrendbe szedve kapjuk a $v_{p, q}$ vektort. Az egyértelmüség kedvéért, ha két vagy három egyforma nagyságú érték fordul elő, amelyek közt különböző előjelüek is vannak, pl. $(n,-n, \pm 1)$, beleértve az $(1,-1, \pm 1)$ 
esetet is, akkor $v(1)>0$ és $v(2)<0$. Ekkor $v_{p, q}$ multihalmazként tekintve megegyezik $w_{p, q}$-val, ráadásul $|v(i)| \geq|v(j)|$ ha $i<j$ is fennáll $(1 \leq i, j \leq 3)$. A $v_{p, q}$ vektort rendezett különbségvektornak nevezzük. Amikor az egyértelmüséget nem veszélyezteti, el fogjuk hagyni a $p, q$ indexpárt. Továbbá $p, q \in H$ esetén legyen $\delta_{p, q}=1$, ha $p$ és $q$ paritása különbözik; és $\delta_{p, q}=0$, ha $p$ és $q$ azonos paritású.

Érdemes megemlíteni, hogy szabályos hatszögrácshoz jutunk, ha az élen osztozó háromszögek középpontjait élekkel összekötjük, vagyis a két rács egymás duálisa.

\section{Digitális távolságok rögzített szomszédsággal}

A dolgozatban a távolság fogalma központi szerepet játszik. Általában a metrikus tulajdonságokat teljesítő függvényeket szokás jó távolságoknak tekinteni. Egy $d: H \times H \rightarrow \mathbb{R}^{\geq 0}$ távolságfüggvényről akkor mondjuk, hogy metrikus tulajdonságú, ha bármely $p, q, r$ pontok esetén teljesülnek a következő feltételek:

1. $d(p, q) \geq 0$ (nemnegativitás),

2. $d(p, q)=0$, akkor és csak akkor, ha $p=q$ (egyediség),

3. $d(p, q)=d(q, p)$ (szimmetria),

4. $d(p, q)+d(q, r) \geq d(p, r)$ (háromszög-egyenlőtlenség).

A három lehetséges szomszédságnak megfelelően, a háromszögrács pixeleit különböző típusú utakkal köthetjük össze:

3.1. Definíció. Egy véges $\Pi(p, q ;(k))$ pontsorozatot - ami $p=p_{0}, p_{1}, \ldots, p_{m}=$ $q$ formába írható, ahol $p_{i-1}$ és $p_{i} k$-szomszédok minden $1 \leq i \leq m$ esetén egy $k$-szomszédságú $p$-ből $q$-ba vezető útnak hívunk. $\mathrm{A} \Pi(p, q ;(k))$ út hossza $|\Pi(p, q ;(k))|=m$. A $p$-ből $q$-ba vezető legrövidebb utat (vagy ezek egyikét) jelölje $\Pi^{*}(p, q ;(k))$. Ekkor $p$ és $q(k)$-távolságát definiáljuk ezen út hosszával: $d(p, q ;(k))=\left|\Pi^{*}(p, q ;(k))\right|$.

A következő eredmény megtalálható a [26, 36] cikkekben.

3.1. TÉTEL. Legyen $p=(p(1), p(2), p(3))$ és $q=(q(1), q(2), q(3))$ a háromszögrács két pontja, ekkor a távolságuk a következő képletekkel határozható meg:

$d(p, q ;(1))=\sum_{i \in\{1,2,3\}}|p(i)-q(i)|=|p(1)-q(1)|+|p(2)-q(2)|+|p(3)-q(3)|$,

$d(p, q ;(2))=\left\lceil\frac{|p(1)-q(1)|+|p(2)-q(2)|+|p(3)-q(3)|}{2}\right\rceil=\left\lceil\frac{d(p, q ;(1))}{2}\right\rceil$,

$d(p, q ;(3))=\max _{i \in\{1,2,3\}}\{|p(i)-q(i)|\}$.

3.1. Példa. d((0,0,0), (1, 1, -1); (1)) = 3, d((0,0,0), (1, 1, -1); (2)) = 2, $d((0,0,0),(1,1,-1) ;(3))=1, \quad d((0,0,0),(5,-2,-2) ;(1))=9$, $d((0,0,0),(5,-2,-2) ;(2))=d((0,0,0),(5,-2,-2) ;(3))=5$, $d((1,1,-1),(5,-2,-2) ;(2))=d((1,1,-1),(5,-2,-2) ;(3))=4$. 
Két pont (1)-távolsága akkor és csak akkor páros, ha a két pont paritása megegyezik. Továbbá a távolságok között a következö összefüggések teljesülnek: Egyrészt bármely két pont (2)-távolsága fele az (1)-távolságuknak (felfele kerekítve, ha az (1)-távolság páratlan). Másrészt, két pont (2)-távolsága és (3)-távolsága közt legfeljebb 1 a különbség a kétféle megengedett koordinátaösszeg miatt (ha ez a két távolság különböző értékü két pont esetén, akkor a (3)-távolságuk a kisebb, ilyen esetben azt mondjuk, hogy a két pont szerencsés irányban van egymáshoz képest). Ha a két pont paritása megegyezik, akkor viszont a (2)-távolságuk biztosan pont akkora, mint a (3)-távolságuk. A szerencsés irányt formálisan is definiáljuk, mert később fontos szerepet játszik.

Formálisan legyen $\sigma_{p, q}=1$, ha $p$ páros és $w_{p, q}$ két pozitív és egy negatív értéket tartalmaz, vagy $p$ páratlan és $w_{p, q}$-ban egy pozitív és két negatív érték van (vagyis $p$-tól $q$ szerencsés irányban van). Egyébként pedig legyen $\sigma_{p, q}=0$, beleértve azokat az eseteket is, amikor $p$ és $q$ pont egy sávon van, vagyis van közös koordinátájuk. A szerencsés irány fogalma azzal kapcsolatos, hogy egy adott pontból a paritásától függően csak a hat lehetséges szigorú 3-szomszéd vektor fele használható, vagyis egy páros pont esetén az $(1,1,-1),(1,-1,1),(-1,1,1)$ irányok, amíg páratlan pont esetén $(1,-1,-1),(-1,1,-1)$ és $(-1,-1,1)$ azok a lépések, amik 2-szomszédra történő lépésekkel nem elérhetőek. Ezek alapján vannak olyan irányok, amelyekben kihasználható a 3-as szomszédság, és vannak irányok, ahol „csak” ugyanannyit ér, mint a 2-es. Ezekre a távolságokra igaz a következő ([26]):

3.2. TÉTEL. A háromszögrácson a $(k)$-távolság, $k \in\{1,2,3\}$ esetekben metrikus távolság függvényt definiál.

\section{Szomszédsági sorozatok a háromszögrácson}

Az előző fejezetben bemutatott három digitális távolság egyik kézenfekvő általánosítása, ha a pontokat összekötö út során lépésenként szabályozhatjuk, mely szomszédság megengedett [22, 29, 31]. Ebben a fejezetben az ilyen távolságokat mutatjuk be.

4.1. Definíció. A $B=(b(i))_{i=1}^{\infty}$ sorozatot, ahol $b(i) \in\{1,2,3\}$ minden $i \in \mathbb{N}$ értékre, szomszédsági sorozatnak hívjuk. Ha van olyan $l \in \mathbb{N}$, hogy $b(i)=b(i+l)$ fennáll minden $i \in \mathbb{N}$ esetén, akkor $B$ periodikus $l$ periódussal. Ebben az esetben egy periódusnyi elemmel megadhatjuk a sorozatot: $B=(b(1), \ldots, b(l))$. Legyen $p$ és $q$ két pont és $B=(b(i))_{i=1}^{\infty}$ egy szomszédsági sorozat. Egy véges $\Pi(p, q ; B)$ pontsorozatot - ami $p=p_{0}, p_{1}, \ldots, p_{m}=q$ formába írható, ahol $p_{i-1}$ és $p_{i} b(i)$ szomszédok minden $1 \leq i \leq m$ esetén - $p$-böl $q$-ba vezető $B$-útnak hívunk. Az út hossza, és ez alapján a $B$-távolság a 3.1. definícióval analóg módon adható meg: $d(p, q ; B)=\left|\Pi^{*}(p, q ; B)\right|$. 
Legrövidebb út előállítása bármely két pont között történhet mohó algoritmussal (lásd pl. [16, 18]), ami röviden így írható le:

Legyen adott a kezdő- és a végpont ( $p$ és $q$ ), valamint egy $B$ szomszédsági sorozat. Legyen $j=0$ és $x_{0}=p$ az út első pontja. Amíg $x_{j} \neq q$, addig egy ciklusban hajtsuk végre a következő számolást:

Számoljuk ki $q$ és $x_{j} w$ különbségvektorát, továbbá adjunk egyet $j$ értékéhez. A $b(j)$ értéke alapján három eset van: ha $b(j)=1$, akkor a $v(1)$ és $v(2)$ értékekhez tartozó különbségek közül a lépés azt csökkenti, amit $x_{j-1}$ paritása megenged. Ha $b(j)=2$, és $w$-ben van legalább két nem nulla érték, akkor csökkentsük a $v(1)$ és $v(2)$ értékekhez tartozó elemet. Ha $w$-ben csak egy nem nulla elem van, akkor lépjünk $q$-ra pontosan úgy, mintha $b(j)=1$ lenne. Végül, ha $b(j)=3$, akkor, ha $x_{j-1}$-től $q$ szerencsés irányban van, akkor mindhárom koordinátakülönbséget csökkentjük, egyébként csak olyat lépünk, mintha $b(j)=2$ állna fenn.

Füzzük a lépés után kapott új $x_{j}$ pontot az úthoz.

Az algoritmus konstans tár-bonyolultságú, és a pontok koordinátakülönbségösszegével arányosan lineáris időbonyolultságú. Az algoritmus egy legrövidebb $B$-út mellett a két pont $B$-távolságát is megadja.

4.1. Megjegyzés. Bármely két pont B-távolsága függ a pontok különbségvektorától és paritásától, valamint a szomszédsági sorozattól.

\subsection{Képlet a távolságszámításhoz}

Mivel - a háromszögrács sajátosságai miatt - egy $b(i)=3$ választással nem mindig tudunk „közelebb” kerülni a célponthoz, mint ha csak $b(i)=2$ lenne, bevezetjük a minimális ekvivalens sorozatok fogalmát ([17]).

4.2. Definíció. Egy $B$ szomszédsági sorozat minimális ekvivalens sorozatán a következő tulajdonságokkal rendelkező $B^{\prime}$ szomszédsági sorozatot értjük.

1. $d(p, q ; B)=d\left(p, q ; B^{\prime}\right)$ bármely $p, q$ pontpárra; és

2. minden olyan $B_{1}$ szomszédsági sorozatra, amire $d(p, q ; B)=d\left(p, q ; B_{1}\right)$ minden $p, q$ pontpárra, teljesül, hogy $b^{\prime}(i) \leqslant b_{1}(i)$ minden $i$-re.

4.1. Segédtétel. Egy $B$ szomszédsági sorozat $B^{\prime}$ minimális ekvivalens sorozata egyértelmüen meghatározott:

1. $b^{\prime}(i)=b(i)$, ha $b(i)<3$,

2. $b^{\prime}(i)=3$, ha $b(i)=3$ és nincs olyan $j<i$, amire $b^{\prime}(j)=3$,

3. $b^{\prime}(i)=3$, ha $b(i)=3$ és van olyan $b^{\prime}(l)=3$, hogy $l<i$, de $\sum_{k=j+1}^{i-1} b^{\prime}(k)$ páros, ahol $j=\max \left\{l \mid l<i, b^{\prime}(l)=3\right\}$,

4. $b^{\prime}(i)=2$, különben. 
Az előző eredmény azért is érdekes, mert azt mutatja, hogy pl. a négyzetráccsal ellentétben, a háromszögrácson vannak olyan különböző szomszédsági sorozatok, amelyek ugyanazt a távolságfüggvényt definiálják. Ha a pontok iránya a $B$ sorozat első 3-as eleme szempontjából nem szerencsés, akkor az nem használható ki, ezért bevezetjük a következő fogalmat is.

4.3. Definíció. A $B^{\prime \prime}$ szomszédsági sorozatot a $B$ csökkentett minimális ekvivalens sorozatának hívjuk, ha

1. $b^{\prime \prime}(k)=2$, ahol $k$ az első $B$-ben előforduló 3 helye;

2. $b^{\prime \prime}(i)=b^{\prime}(i)$, minden más $i$-re, ahol $b^{\prime}(i)$-k $B$ minimális ekvivalens sorozatának elemei.

A távolságszámításhoz, pl. ha a két pont egy sávon fekszik, szükség lesz egy további származtatott sorozatra:

4.4. Definíció. Egy $B$ szomszédsági sorozat 2-korlátozott sorozatának nevezzük azt a sorozatot, amelyet $B$-böl a 3-asok 2-esre cserélésével kapunk: $B^{(2)}=$ $\left(b^{(2)}(i): i \in \mathbb{N}\right)$.

Eredetileg a távolságképlet megadásához elöször a 3 dimenziós kockarácsban vett képletet bizonyítottuk [23, 27], és abból származtattuk az eredményt a háromszögrácsra az előbb bevezetett származtatott szomszédsági sorozatok segítségével.

4.1. TÉtel. Legyen $p, q \in H$ és $B$ egy szomszédsági sorozat. Legyen $k=$ $\min \{i \mid b(i)=3\}$ a legkisebb olyan érték, amelyre $b(k)=3$, vagy, ha a 3 -as nem szerepel $B$-ben, akkor $k=\infty$. Jelölje $d_{m}, d_{c}$ és $d_{k}$ az alább definiált értékeket, amiket rendre $B$ minimális ekvivalens sorozatával, $B^{\prime}$-vel; a $B$ csökkentett minimális ekvivalens sorozatával, $B^{\prime \prime}$-vel; illetve $B$ 2-korlátozott sorozatával, $B^{(2)}$-vel számolunk:

$$
\begin{gathered}
d_{m}=\max \left\{i\left|\sum_{\ell=1}^{3}\right| v(\ell) \mid>\sum_{j=1}^{i-1} b^{\prime}(j)\right\}, d_{c}=\max \left\{i\left|\sum_{l=1}^{3}\right| v(l) \mid>\sum_{j=1}^{i-1} b^{\prime \prime}(j)\right\} \\
d_{k}=\max \left\{i\left|\sum_{l=1}^{2}\right| v(l) \mid>\sum_{j=1}^{i-1} b^{(2)}(j)\right\}, \text { továbbá, } \\
d^{\prime}=\max \left\{|v(1)|, d_{k}, d_{m}\right\}, \text { és } d^{\prime \prime}=\max \left\{|v(1)|, d_{k}, d_{c}\right\} .
\end{gathered}
$$

Ekkor $d(p, q ; B)=d^{\prime \prime}$, ha $d^{\prime} \geq k$ és az alábbi esetek egyike fennáll: $B$ nem tartalmaz 3-ast; vagy $\sigma_{p, q}=0$ és $\sum_{i=1}^{k-1} b(i)$ páros, vagy $\sigma_{p, q}=1$ és $\sum_{i=1}^{k-1} b(i)$ páratlan.

Minden a fentiektől eltérő esetben $d(p, q ; B)=d^{\prime}$.

Most néhány érdekes példát mutatunk. 
4.1. Példa. Legyenek adottak $p=(0,0,0), q=(1,1,-1), r=(1,1,-2)$ és $s=$ $(2,1,-2)$ pontok. Ekkor $d(p, q ;(2,1,1))=2, d(p, r ;(2,1,1))=3, d(p, s ;(2,1,1))=$ $4, d(q, s ;(2,1,1))=1$, tehát, $d(p, q ;(2,1,1))+d(q, s ;(3,1))<d(p, s ;(3,1))$ vagyis a $(2,1,1)$-távolság nem metrikus, mert nem teljesíti a háromszög-egyenlőtlenséget. Továbbá, $d(p, r ;(3,1))=2, d(p, s ;(3,1))=3, d(p, q ;(3,1))=1, d(q, s ;(3,1))=1$, $d(r, p ;(3,1))=3$, így, $d(p, r ;(3,1)) \neq d(r, p ;(3,1))$ és $d(p, q ;(3,1))+d(q, s ;(3,1))<$ $d(p, s ;(3,1))$, vagyis a $(3,1)$-távolság nem szimmetrikus (és nem metrikus).

\subsection{Metrikus és nem metrikus távolságok}

A háromszögrácson szomszédsági sorozatok esetén a háromszögegyenlőtlenséggel és a szimmetriával is gond lehet (ahogy a 4.1. példában is láttuk), így kicsit más a helyzet, mint a négyzetrácson, ahol csak a háromszögegyenlőtlenség sérülhet bizonyos sorozatok által definiált távolság esetén. A következő eredmény egy szükséges és elégséges feltételt ad a szimmetria tulajdonság ellenőrzésére [17].

4.2. SEgÉdTÉTEL. Egy B-távolság pontosan akkor nem teljesíti a szimmetria tulajdonságot, ha van olyan $i \in \mathbb{N}$, hogy $b(i)=3$, és fennáll legalább a következő esetek egyike az $i=\min \{l \mid b(l)=3\}$ értékkel:

$\sum_{k=1}^{i-1} b(k)$ páratlan; vagy van olyan $j$, amire $b(j)=1$ és $i<j$.

A háromszög-egyenlőtlenség ellenőrzése a következőképpen lehetséges [20, 24, 28]:

4.3. SEGÉDtétel. Legyen adott a $B$ szomszédsági sorozat, jelölje $B^{(2)}$ a $B$ 2-korlátozott sorozatát, valamint $B^{\prime}$ a $B$ minimum ekvivalens sorozatát. $A$ háromszög-egyenlőtlenség pontosan akkor teljesül a $B$-távolságra, ha minden $i, j \in$ $\mathbb{N}$ számpárra fennáll, hogy $\sum_{k=1}^{i} b^{(2)}(k) \leq \sum_{k=j+1}^{j+i} b^{(2)}(k)$ és $\sum_{k=1}^{i} b^{\prime \prime}(k) \leq \sum_{k=j+1}^{j+i} b^{\prime}(k)$, ahol $B^{\prime \prime}=B^{\prime}$ a $B$ minimális ekvivalens sorozata, ha $\sum_{k=1}^{j} b^{\prime}(k)$ páros és $B^{\prime \prime}$ a $B$ csökkentett minimális ekvivalens sorozata egyébként.

Az előzőek alapján kimondjuk a tételt:

4.2. TÉtel. Legyen $B$ egy szomszédsági sorozat. A B-távolság pontosan akkor metrikus, ha teljesülnek a következők:

1. ha $b(j)=3$ és $b(i)=1$, akkor $i<j$;

2. ha $B$-ben szerepel a 3 , akkor $B$-ben páros darab 1-es van;

3. $\sum_{k=1}^{i} b(k) \leqslant \sum_{k=j+1}^{j+i} b(k)$, ahol $i+j<l$, arra az $l$-re, ami a $B$-ben levö elsö 3 -as helye, (ha nincs 3 -as $B$-ben, akkor a feltételnek minden $i, j \in \mathbb{N}$ párra fenn kell állnia). 
A következő következmények a [31] könyvfejezetből valók.

4.3. TÉtel. $\operatorname{Egy} d(p, q ; B)>k$ B-távolság függ $B$ első $k$ elemének sorrendjétől, ha azoknak van olyan permutációja, amellyel a $B$-távolság nem szimmetrikus.

4.1. KÖvetKezmÉny. Legyen $B$ egy periodikus szomszédsági sorozat. Ekkor a B-távolság akkor és csak akkor metrikus, ha a következő két feltétel egyike fennáll.

1. $B$ nem tartalmazza a 3 értéket, és $\sum_{k=1}^{i} b(k) \leq \sum_{k=j+1}^{j+i} b(k)$ minden $i, j \in \mathbb{N}$ esetén;

2. $B$ nem tartalmazza az 1 értéket.

\subsection{Digitális körök}

A digitális távolságok jellemzése történhet a digitális körök segítségével:

4.5. Definíció. Legyen adott egy $d(p, q)$ digitális távolság és egy nemnegatív $k \in \mathbb{R}$ sugár, ekkor az o középpontú $k$ sugarú digitális kör a következő halmaz:

$$
C_{k}^{d}=\{p \mid d(o, p) \leq k\}
$$

Itt jegyezzük meg, hogy a digitális kör ezen definíciója nem a körvonal, hanem a körlap digitális változatának, a digitális diszknek felel meg.

Amennyiben szomszédsági sorozattal definiáljuk a digitális távolságot, a $C_{k}^{d}$ jelölésben $d$ helyére a $B$ sorozatot írhatjuk. Négyzetrácson hasonló értelemben az $O_{k}^{d}=\{p \mid d(o, p) \leq k\}$ jelölést használjuk. Világos, hogy egy $k$ sugarú digitális kör csak a $B$ sorozat első $k$ elemétöl függ.

Ezen körök jellemzése különböző szempontok alapján megtalálható a [7, 21, 25, 33, 39] cikkekben, itt néhány fontos megállapítást közlünk róluk röviden. A négyzetrácson a különböző szomszédsági sorozattal generált, de egyező sugarú digitális körök egy jól rendezett halmazt alkotnak. Ez háromszögrácson nem teljesül. A négyzetrácson $O_{k}^{B}$ nem függ $B$ első $k$ elemének sorrendjétől. Ezzel szemben a háromszögrácson pl. $C_{2}^{(1,3)}$ és $C_{2}^{(3,1)}$ két, egymással nem összemérhető ponthalmazt jelöl. Ahogyan a négyzetrácson, úgy a háromszögrácson is igaz viszont, hogy a $k$ sugár növekedtével az ugyanazzal a szomszédsági sorozattal generált $B$-körök szigorúan monoton nőnek, vagyis: ha $k>l$, akkor $C_{k}^{B} \supsetneq C_{l}^{B}$. A négyzetrácson nem fordulhat elő, hogy két szomszédsági sorozatra a különböző sugarú körök megegyezzenek. Ezzel szemben pl. $C_{2}^{(1)}=C_{1}^{(2)}$. Adott $B$ szomszédsági sorozat és minimális ekvivalens sorozata, $B^{\prime}$ ugyanazt a digitális körsorozatot generálja, vagyis $C_{k}^{B^{\prime}}=C_{k}^{B}$ bármely $k \in \mathbb{N}$ esetén. Ezzel szemben a négyzetrácson ha egy $B_{1}$ sorozat elemenként nem kisebb egy másik $B_{2}$ sorozatnál, és van olyan $i \in \mathbb{N}$, hogy $b_{1}(i)>b_{2}(i)$, akkor minden legalább $i$ sugarú köreikre $(k \geq i)$ igaz, hogy $O_{k}^{B_{1}} \supsetneq O_{k}^{B_{2}}$. A digitális körök, illetve a szomszédsági sorozatok előbb említett érdekes tulajdonságait kommunikációs hálózatokban is kihasználhatjuk [34]. Egy 
adott szomszédsági sorozat által megszabott módon mintegy hullámfrontként terjedő jel lefedi a megfelelö digitális kör pontjait. Egy „gyorsabb” sorozat által terjedő jel pedig akár később indulva is utolérheti az előzőt. A $B_{f}=(3)$ a leggyorsabb, a $B_{s}=(1)$ a leglassabb sorozat ilyen értelemben.

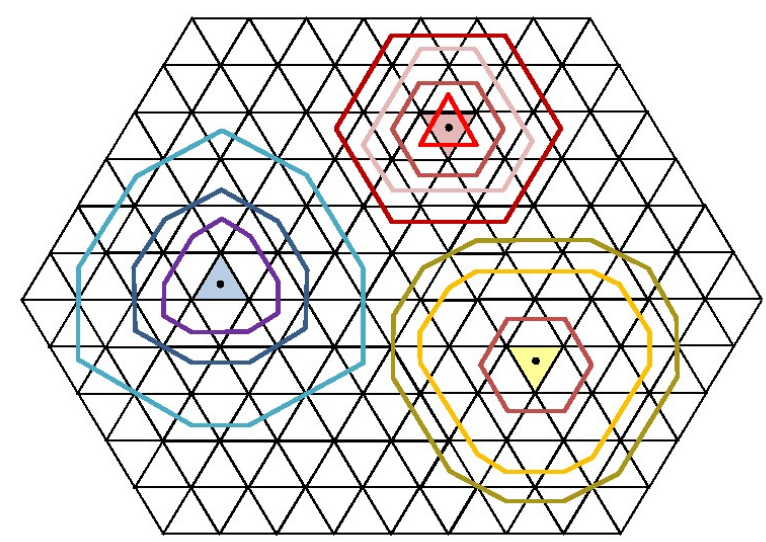

2. ábra. Digitális körök szomszédsági sorozatok segítségével, $B_{1}=(3,1,3)$ balra, $B_{s}=(1,1,1,1)$ fent és $B_{2}=(2,3,1)$ jobbra lent.

A köröket a továbbiakban a digitális kör által tartalmazott háromszögcsempék középpontjai által meghatározott legkisebb területű konvex síkidommal azonosítjuk. Igaz továbbá, hogy ezen digitális körök digitálisan konvexek, vagyis ezek a síkidomok nem tartalmaznak olyan háromszögcsempe középpontot, amely nem eleme a digitális körnek. Az egy pontból induló, szomszédsági szekvenciával generált hullámfrontokkal láthatjuk, hogy a háromszögrácson a digitális körök tulajdonképpen sokszögek [25], ahogy a 2. ábra is mutatja.

4.4. TÉTEL. Egy $B$ szomszédsági sorozat által definiált $k$ sugarú kör alakja - háromszög: $C_{1}^{(1)}$, akkor és csak akkor, ha $k=1$, és $b(1)=1$;

- hatszög, ha $B$ felhasznált elemei közt nincs 3-as (kivéve az elöző esetet);

- kilencszög, ha $B$ felhasznált elemei közt nincs 2-es, továbbá nincs két egymás melletti azonos érték (kivéve az első esetet);

- tizenkétszög, minden az elöző esetekbe nem illő esetben.

A fentiek alapján a háromszögrácson szomszédsági sorozatokkal jobban közelíthető az euklideszi távolság és kör, mint a négyzetrácson [7, 30, 39]. Ez utóbbin a digitális körök négyzetek, ha csak egyféle lépést használunk, ezzel „megoldva” a kör négyszögesítését a digitális sík felhasználásával [13, 35], illetve általános esetben nyolcszögek (ezért hívják oktogonális távolságoknak is a szomszédsági sorozatokkal definiált távolságokat [4]). 


\section{Súlyozott távolságok a háromszögrácson}

A 3-szomszédságú utakat ebben a fejezetben egyszerüen utaknak nevezzük.

5.1. Definíció. Legyenek $\alpha, \beta, \gamma$ pozitív súlyok. Ekkor bármely $\Pi(p, q): p=$ $p_{0}, p_{1}, \ldots, p_{m}=q$ úthoz hozzárendelhető az $n_{1} \alpha+n_{2} \beta+n_{3} \gamma$ súly, ahol $n_{1}$ a П-ben levő 1-szomszéd $\left(p_{i}, p_{i+1}\right)$ pontpárok száma, $n_{2}$ a szigorú 2 -szomszéd $\left(p_{i}, p_{i+1}\right)$ pontpárok száma, valamint $n_{3}$ a szigorú 3 -szomszéd $\left(p_{i}, p_{i+1}\right)$ pontpárok száma $(0 \leq i<m)$. A $p$ és $q$ közti legkisebb súlyú út súlya adja a pontok $(\alpha, \beta, \gamma)$ súlyokkal vett súlyozott távolságát, amit $d(p, q ; \alpha, \beta, \gamma)$ jelöl.

Itt jegyezzük meg, hogy egyes terminológia szerint súlyozott távolság esetén csak akkor beszélnek digitális távolságról, ha a távolság (vagyis a használt súlyok) értéke egész. Cikkünkben a természetes $0<\alpha \leq \beta \leq \gamma$ feltételt alkalmazzuk.

\subsection{A távolság számítása}

Nemcsak maga a súlyozott távolság, de az is függ maguktól a súlyoktól is, hogy mely út súlya lesz a legkisebb. Ennek megfelelően a következő tétel adja meg, hogy milyen feltételek esetében mely formula adja meg a súlyozott távolságot két tetszőleges pont között [32]. Ahogy a korábbiakban láttuk, nem csupán a pontok koordináta különbsége, de a pontok paritása, és egymáshoz viszonyított iránya is fontos szerepet játszik a legrövidebb út és a távolság meghatározásában.

5.1. TÉTEL. Legyenek $\alpha, \beta, \gamma$ pozitív súlyok, valamint $p=(p(1), p(2), p(3))$ és $q=(q(1), q(2), q(3))$ a háromszögrács két pontja. Ekkor $p$ és $q(\alpha, \beta, \gamma)$ súlyokkal vett súlyozott távolsága:

1. Ha $2 \alpha \leq \beta$ és $3 \alpha \leq \gamma$, akkor $d(p, q ; \alpha, \beta, \gamma)=\alpha d(p, q ;(1))$.

2. Ha $2 \alpha>\beta$ és $3 \alpha \leq \gamma$, akkor $d(p, q ; \alpha, \beta, \gamma)=\beta\left\lfloor\frac{d(p, q ;(1))}{2}\right\rfloor+\delta_{p, q} \alpha$.

3. Ha $2 \alpha>\beta, 3 \alpha>\gamma$ és $\alpha+\beta \leq \gamma$, akkor $d(p, q ; \alpha, \beta, \gamma)=\beta\left\lfloor\frac{d(p, q ;(1))}{2}\right\rfloor+\delta_{p, q} \alpha$.

4. Ha $2 \alpha>\beta, 3 \alpha>\gamma, \alpha+\beta>\gamma$ és $2 \beta<\gamma+\alpha$, akkor: $d(p, q ; \alpha, \beta, \gamma)= \begin{cases}\beta \frac{d(p, q ;(1))}{2} & \text { ha } \delta_{p, q}=0, \\ \beta \frac{d(p, q ;(1))-3}{2}+\gamma & \text { ha } \delta_{p, q}=1, \sigma_{p, q}=1, \\ \beta \frac{d(p, q ;(1))-1}{2}+\alpha & \text { egyébként. }\end{cases}$

5. Ha $2 \alpha>\beta, 3 \alpha>\gamma, \alpha+\beta>\gamma$ és $\gamma+\alpha \leq 2 \beta$, akkor $d(p, q ; \alpha, \beta, \gamma)=$ $\alpha\left(|v(3)|+\delta_{p, q}(-1)^{\sigma_{p, q}}+\beta \frac{|v(1)|+|v(2)|-3|v(3)|+\delta_{p, q}(-1)^{1-\sigma_{p, q}}}{2}+\gamma|v(3)|\right.$.

6. Végül, ha $2 \alpha \leq \beta$ és $3 \alpha>\gamma$, akkor $d(p, q ; \alpha, \beta, \gamma)=\alpha(|v(1)|+|v(2)|-2|v(3)|)+\gamma|v(3)|$. 
Most példát adunk mindegyik esetre egészértékű súlyokkal.

5.1. Példa. Legyen $p=(0,0,0), q=(2,2,-3)$ és $r=(-3,-2,5)$. Ekkor $\alpha=$ $2, \beta=5$ és $\gamma=6$ súlyválasztás megfelel az első esetnek, ekkor $d(p, q ; 2,5,6)=14$. Legyen most $\alpha=2, \beta=3$ és $\gamma=7$. Ezen súlyok a második esetnek felelnek meg, így $d(p, q ; 2,3,7)=11$ és $d(p, r ; 2,3,7)=15$. Az $\alpha=3, \beta=4, \gamma=8$ súlyhármas a harmadik esetre példa; $d(p, q ; 3,4,8)=15$. A negyedik esetet szemlélteti az $\alpha=4, \beta=5, \gamma=8$ súlyhármas. Így $d(p, q ; 4,5,8)=18$ és $d(p, r ; 4,5,8)=25$ adódik. Továbbá, $\alpha=4, \beta=7, \gamma=8$ választás az ötödik esetbe esik.. Ezekkel a súlyokkal $d(p, q ; 4,7,8)=20$ és $d(p, r ; 4,7,8)=31$. Végül, $\alpha=3, \beta=7, \gamma=8$ az utolsó esetre példa; ezesetben $d(p, q ; 3,7,8)=19$ és $d(p, r ; 3,7,8)=28$.

A különböző súlyeloszlásokhoz tartozó optimális megoldásokat lineáris egészértékü programozás segítségével írtuk le a [11] cikkben.

\subsection{Súlyozott távolságok tulajdonságai és digitális körök}

A súlyozott távolságok bizonyos szempontból jobban viselkednek a szomszédsági sorozatokkal definiált távolságoknál, ugyanis a súlyozott utak megfordíthatóak, illetve összefüzhetőek, aminek következménye a következő eredmény ([32]).

5.2. TÉTEL. A súlyozott távolság bármilyen pozitív súlyhármas esetén metrikus.

A digitális körök esetén a távolságot itt az $\alpha, \beta, \gamma$ súlyhármassal azonosítjuk (és ezt írjuk a felső indexbe: $C_{k}^{\alpha, \beta, \gamma}$ ). A természetes $\alpha \leq \beta \leq \gamma$ feltétel teljesülése esetén az $\alpha, \beta, \gamma$ súlyokkal definiált digitális körök mindig digitálisan konvexek. Néhányat bemutatunk a 3. ábrán. A leírásukhoz geometriai, kombinatorikai [15, 38] és operációkutatási módszerek is alkalmazhatóak [10,12]. Többek között egy 18szög alakú digitális kört írtunk le Chvátal-vágás alkalmazásával [12], és egy 63-szög alakú digitális kört is megadtunk [15]. Ezzel szemben a négyzetrácson a hagyományos két szomszédság segítségével, két súllyal, a digitális köröknek legfeljebb 8 csúcsa lehet. Ez egy olyan kutatási irány, amely jelenleg is aktív. Így ez a terület átvezet minket a következő kitekintő fejezetbe.
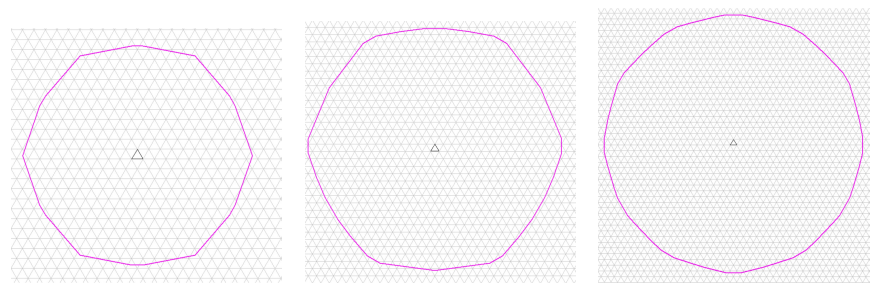

3. ábra. Digitális körök súlyozott távolságokkal, $C_{100}^{6,10,12}$ balra, 18-szög; $C_{200}^{7,13,17}$ középen, 27-szög és $C_{299}^{8,15,18}$ jobbra, 48-szög. 


\section{6. Összefoglalás és további kapcsolódó kutatási irányok}

A digitális távolságok elméletét foglaltuk össze a háromszögrácson, képletet adtunk a távolság kiszámítására két tetszőlegesen adott háromszögcsempe között, a távolságok metrikusságát is vizsgáltuk. Ezen távolságok nemcsak matematikai szempontból érdekesek, hanem azért is, mert hasonlóan a digitális távolságok négyzetrácson való alkalmazásához, változatos módon használhatóak pl. a digitális képfeldolgozás területén. Kapcsolódó kutatások folyamatban vannak a digitális körökkel kapcsolatosan. Mint láthattuk, a digitális térben sokszor nem egy legrövidebb út van két pont között. A legrövidebb utak számát a háromszögrácson mint kombinatorikai problémát a [6, 36, 37] cikkekben vizsgáltuk.

\section{Köszönetnyilvánítás}

A szerző köszöni a társszerzőinek a közös munkát és a lektorok megjegyzéseit.

\section{Hivatkozások}

[1] G. Borgefors: Distance transformations in arbitrary dimensions: Comput. Vision Graphics Image Process., Vol. 27, pp. 321-345 (1984).

[2] P.P. Das, P.P. Chakrabarti and B.N. Chatterji: Distance functions in digital geometry, Inform. Sci., Vol. 42, pp. 113-136 (1987).

[3] P.P. Das, P.P. Chakrabarti and B.N. Chatterji: Generalised distances in digital geometry, Inform. Sci., Vol. 42, pp. 51-67 (1987).

[4] P.P. Das and B.N. ChatterJi: Octagonal distances for digital pictures, Inform. Sci., Vol. 50, pp. 123-150 (1990).

[5] E.S. Deutsch: Thinning algorithms on rectangular, hexagonal and triangular arrays, Communications of the ACM, Vol. 15 pp. 827-837 (1972).

[6] M. Dutt, A. Biswas And B. Nagy: Number of Shortest Paths in Triangular Grid for 1and 2-Neighborhoods, IWCIA'15, LNCS Vol. 9448, pp. 115-124 (2015).

DOI: 10.1007/978-3-319-26145-4_9

[7] A. Hajdu and B. Nagy: Approximating the Euclidean circle using neighbourhood sequences, 3. KÉPAF konferencia, Domaszék, pp. 260-271 (2002).

[8] P. Kardos and K. Palágyi: Topology preservation on the triangular grid, Ann. Math. Artif. Intell. Vol. 75, pp. 53-68 (2015). DOI:10.1007/s10472-014-9426-6

[9] R. Klette and A. Rosenfeld: Digital geometry: Geometric methods for digital picture analysis, Morgan Kaufmann, San Francisco, CA; Elsevier, Amsterdam, p. xiii+655 (2004).

[10] G. Kovács, B. Nagy and B. VizváRI: An Integer Programming Approach to Characterize Digital Disks on the Triangular Grid, DGCI 2017, LNCS Vol. 10502, pp. 94-106 (2017). DOI: 10.1007/978-3-319-66272-5_9 
[11] G. Kovács, B. Nagy and B. VizvÁRI: Chamfer distances on the isometric grid: a structural description of minimal distances based on linear programming approach, Journal of Combinatorial Optimization, Vol. 38, pp. 867-886 (2019). DOI: 10.1007/s10878-019-00425-x

[12] G. Kovács, B. Nagy And B. Vizvári: On disks of the triangular grid: An application of optimization theory in discrete geometry, Discrete Applied Mathematics Vol. 282, pp. 136151 (2020). DOI: 10.1016/j.dam.2019.11.018

[13] S. Marchand-Maillet and Y.M. Sharaina: Binary Digital Image Processing: A Discrete Approach, Elsevier Publishing Company, Amsterdam, p. 251 (2000).

[14] R.A. Melter and I. Tomescu: Path generated digital metrics, Pattern Recognition Lett., Vol. 1, pp. 151-154 (1983).

[15] H. Mir-Mohammad-Sadeghi and B. Nagy: On the Chamfer Polygons on the Triangular Grid, IWCIA 2017, LNCS Vol. 10256, pp. 53-65 (2017). DOI: 10.1007/978-3-319-59108-7_5

[16] B. NAGY: Finding shortest path with neighbourhood sequences on triangular grids, ISPA'01, 2nd Int. Symp. Image and Signal Proc. and Analysis, Pula, Croatia pp. 55-60 (2001).

[17] B. NagY: Metrics Based on Neighbourhood Sequences in Triangular Grids, Pure Math. Appl., Vol. 13, pp. 259-274 (2002).

[18] B. Nagy: Shortest Path in Triangular Grids with Neighbourhood Sequences, Journal of Comp. and Inf. Techn., Vol. 11, pp. 111-122 (2003).

[19] B. NAGY: A symmetric coordinate system for hexagonal networks, (2004), IS-TCS'04, Proc. Theor. Comp. Sci. - Inform. Soc., Ljubljana, Slovenia, pp. 193-196 (2004).

[20] B. NAGY: Non-metrical distances on the hexagonal plane, PRIA-7-2004, 7th Int. Conf. on Pattern Recog. and Image Anal.: New Information Technologies, St. Petersburg, Russian Federation, pp. 335-338 (2004).

[21] B. NaGY: Characterization of Digital Circles in Triangular Grid, Pattern Recognition Lett. Vol. 25, pp. 1231-1242 (2004). DOI: 10.1016/j.patrec.2004.04.001

[22] B. NAGY: Szomszédsági szekvenciák a háromszögrácson, 4. NJSZT-KÉPAF konferencia, Miskolc, pp. 197-205 (2004).

[23] B. NAGY: Calculating Distance with Neighborhood Sequences in the Hexagonal Grid, IWCIA 2004, LNCS Vol. 3322 pp. 98-109 (2004).

[24] B. Nagy: Metrical and Nonmetrical Distances on the Hexagonal Plane, Pattern Recognition and Image Analysis, Vol. 15, pp. 268-271 (2005).

[25] B. NAGY: Geometry of neighborhood sequences in hexagonal grid, DGCI 2006, LNCS Vol. 4245, pp. 53-64 (2006). DOI: 10.1007/11907350_5

[26] B. NAGY: Digital geometry of various grids based on neighbourhood structures, 6. KÉPAF konferencia, Debrecen, pp. 46-53 (2007).

[27] B. NAGY: Distances with Neighbourhood Sequences in Cubic and Triangular Grids, Pattern Recognition Lett., Vol. 28, pp. 99-109 (2007). DOI: 10.1016/j.patrec.2006.06.007

[28] B. NAGY: Nonmetrical Distances on the Hexagonal Grid Using Neighborhood Sequences, Pattern Recognition and Image Analysis, Vol. 17, pp. 183-190 (2007). DOI: 10.1134/S1054661807020022 
[29] B. NAGY: Theory of Neighborhood Sequences on Hexagonal Grids, ISPA 2007, 5th Int. Symp. Image and Signal Processing and Analysis, Istanbul, Turkey, pp. 391-396 (2007).

[30] B. NAGY: Optimal Neighborhood Sequences on the Hexagonal Grid, ISPA 2007, 5th Int. Symp. Image and Signal Processing and Analysis, Istanbul, Turkey, pp. 310-315 (2007).

[31] B. NAGY: Distances Based on Neighborhood Sequences in the Triangular Grid, in: Computational Mathematics: Theory, Methods and Applications, Nova Science Publishers, pp. 313-351 (2011).

[32] B. NAGY: Weighted Distances on a Triangular Grid, IWCIA 2014, LNCS Vol. 8466, pp. 37-50 (2014). DOI: 10.1007/978-3-319-07148-0_5

[33] B. NAGY: Number of Words Characterizing Digital Balls on the Triangular Tiling, DGCI 2016, LNCS Vol. 9647, pp. 31-44 (2016).

[34] B. NAGY: Application of neighborhood sequences in communication of hexagonal networks, Discrete Applied Mathematics, Vol. 216, pp. 424-440 (2017). DOI: 10.1016/j.dam.2015.10.034

[35] B. NAGY: On the number of shortest paths by neighborhood sequences on the square grid, Miskolc Mathematical Notes, Vol. 21, pp. 285-301 (2020). DOI: 10.18514/MMN.2020.2790

[36] B. Nagy And A. Akkeles: Trajectories and Traces on Non-traditional Regular Tessellations of the Plane, IWCIA 2017, LNCS Vol. 10256, pp. 16-29 (2017).

DOI: $10.1007 / 978-3-319-59108-7 \_2$

[37] B. Nagy and B. Khassawneh: On the Number of Shortest Weighted Paths in a Triangular Grid, Mathematics, Vol. 8 paper 118 (2020). DOI: 10.3390/math8010118

[38] B. Nagy and H. Mir-Mohammad-Sadeghi: Digital Disks by Weighted Distances in the Triangular Grid, DGCI 2016, LNCS Vol. 9647, pp. 385-397 (2016).

DOI: $10.1007 / 978-3-319-32360-2 \_30$

[39] B. NAGY AND R. StRAnd: Approximating Euclidean circles by neighbourhood sequences in a hexagonal grid, Theoretical Computer Science, Vol. 412, pp. 1364-1377 (2011). DOI: 10.1016/j.tcs.2010.10.028

[40] A. Rosenfeld And J.L. Pfaltz: Distance functions on digital pictures, Pattern Recognition, Vol. 1, pp. 33-61 (1968).

[41] I. Stojmenovic: Honeycomb networks: topological properties and communication algorithms, IEEE Trans. Parallel Distrib. Syst., Vol. 8, pp. 1036-1042 (1997).

[42] M. Yamashita And N. Honda: Distance functions defined by variable neighbourhood sequences, Pattern Recognition, Vol. 17, pp. 509-513 (1984).

[43] M. Yamashita And T. IBARAKi: Distances defined by neighbourhood sequences, Pattern Recognition, Vol. 19 pp. 237-246 (1986). 


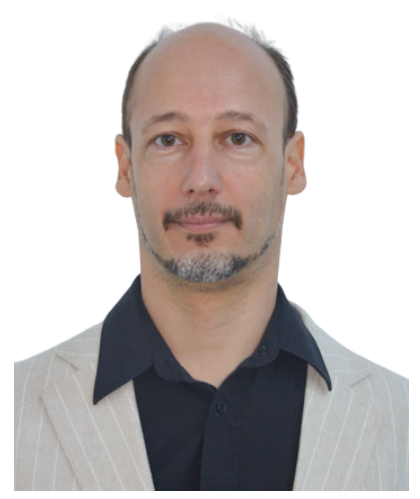

Nagy Benedek 1973-ban született. Tanulmányai: Debreceni Egyetem (KLTE, DE), fizikus (1996), programozó matematikus (1997), filozófus (logika spec., 1998), programtervező matematikus (1999), alkalmazott és általános nyelvész (2000); PhD (2004) és habilitáció (2007), Matematika és Számítástudományok, illetve Informatika tudományterületen. Főbb díjai: Patai László Alapítvány díja (BJMT, 2004), Kemény János Díj (NJSzT, 2006). Vendégkutató: Indiana Egyetem (USA), Rovira i Virgili Egyetem (Spanyolország), Brémai Egyetem (Németország), Uppsala Egyetem (Svédország), Kyoto-Sangyo Egyetem (Japán). 2010 és 2012 között a DE Informatikai Karának dékánhelyettese. Jelenleg a diszkrét matematika és a számítástudomány professzora az Eastern Mediterranean Egyetemen (Famagusta, Ciprus). Főbb kutatási területei: digitális geometria, formális nyelvek, automaták, kombinatorikus képfeldolgozás, számítási paradigmák, mesterséges intelligencia. Szervezője az MCU2015 (Famagusta) és az NCMA2016 (DE), meghívott előadója pl. a DCFS 2019 konferenciának.

\section{NAGY BENEDEK}

Department of Mathematics, Faculty of Arts and Sciences, Eastern Mediterranean University, Famagusta, North Cyprus, via Mersin-10, Turkey

nbenedek.inf@gmail.com

\section{DIGITAL DISTANCES ON THE TRIANGULAR GRID}

\section{BENEDEK NAGY}

One of the three regular tessellations of the plane is the triangular grid. It is based on triangle tiles. Digital spaces, i.e., grids are used in image processing in computer graphics, and the graphs/networks defined by them are also play importance in other disciplines. In digital spaces, digital distances are defined based on (graph theoretical) shortest paths between the tiles (they are also called pixels and points depending on the subdiscipline). The concept of neighbor points plays a crucial role. Paths and digital distances allow to use incremental algorithms and therefore of high importance. There are three types of natural neighborhood on the triangular grid. The symmetric coordinate system describes them nicely. In the basic digital distances the same type of neighborhood is used in each step of the path. By neighborhood sequences, one can vary the used neighborhood criteria step by step along the path giving a large variety of digital distances. However, some of those distance may not meet the triangular inequality and/or not symmetric. Thus, when metricity of the distance function is important, one may use the if and only if condition provided for the neighborhood sequences to check their metricity. Another way to define various digital distances based on various weights assigned to the steps between the various neighbor points. These weighted (also called chamfer) distances are always define metrical distances. Formulae to compute digital distances of the mentioned types are presented, as well as, some further studies, including the description of some digital disks (balls) defined by digital distances.

Keywords: neighborhood sequences, chamfer distances, weighted distances, triangular grid, digital disks. 